But a former member of the laboratory, who wishes to remain anonymous, feels that the research group was increasingly squeezed out in favour of public engagement even before the refurbishments. He questions Greenfield's vision, and whether it was worth the institution selling its property assets to finance the changes. "Greenfield was right, the Royal Institution did need to change. But whether she was right about what it should change into is an open question that will be answered in the coming months," he says. "The redevelopment has cost the entire $£ 15$-million property portfolio and the stakes are extremely high."

Last month, Quentin Pankhurst, deputy director of the London Centre for Nanotechnology, was appointed Catlow's successor. As director of the DFRL he will oversee a team of 15 permanent staff, including three principal investigators as well as several PhD students and postdocs. "I want to create a highly interdisciplinary, close-knit unit here," says Pankhurst, who will retain an affiliation with UCL, which is jointly financing the lab with the Royal Institution. Pankhurst's group will explore health-care biomagnetics, using nanopar-

\section{"We want to show ticles attached to antibodies to that scientists are locate and treat human too." cancers - tech- niques that hark}

back to Faraday's electromagnetic-induction experiments in the early days.

The group will take up 750 square metres of lab space, roughly a third of that available. The rest will go to small start-up companies not affiliated with the DFRL.

Part of Pankhurst's lab will be on public view. "We want to show that scientists are human too," he says. "The open lab won't be populated minute-by-minute, but visitors will see Mössbauer and X-ray techniques as and when the scientists use them."

Pankhurst dismisses concerns that research will play second fiddle to outreach programmes. The Royal Institution's mission statement from 1799 compels it "to facilitate the general introduction of useful inventions and improvements; and to teach...the application of science for the common purposes of life". According to Pankhurst: "These two aspects, which we might now call technology transfer and public engagement, have been and still are central tenets of the Royal Institution." Matt Brown

See Books and Arts, page 595.

\title{
Climate anomaly is an artefact
}

The humble bucket turns out to be at the bottom of a perplexing anomaly in the climate records for the twentieth century.

The time series of land and ocean temperature measurements, begun in 1860 , shows a strange cooling of about $0.3^{\circ} \mathrm{C}$ in the global mean temperature in 1945, relative to the 1961-90 average. The sharpness of the drop stands out even more if the signatures of internal climate variability, such as those associated with El Niño events, are filtered from the record.

This cooling at the end of the Second World War is one of several temperature drops in the record. But unlike others, such as the 1991 cooling caused by the eruption of Mount Pinatubo in the Philippines, it is limited to ocean temperatures and is not associated with any known climatic or geological phenomenon. The nuclear explosions in 1945 over Hiroshima and Nagasaki were ruled out as a possible cause because they are thought to have had no impact on global temperature. Other theories proposed as explanations for the cooling include a massive 1940s El Niño event that had somehow slipped attention, or that it was the result of sulphate aerosols from burning dirty coal. But neither of these was convincing.

A US-British team of climate scientists has now found a surprisingly simple explanation for the long-standing conundrum (page 646). It turns out that the mysterious drop is due to differences in the way that British and US ships' crews measured the sea surface temperature (SST) in the 1940s.

Only a few SST measurements were made during wartime, and almost exclusively by US ships. Then, in the summer of 1945, British ships resumed measurements. But whereas US crews had measured the temperature of the intake water used for cooling the ships' engines, British crews collected water in buckets from the sea for their measurements. When these uninsulated buckets were hauled from the ocean, the temperature probe would get a little colder as a result of the cooling effect of evaporation. US measurements, on the other hand, yielded slightly higher temperatures due to the warm engine-room environment.

The standard logbook entries made at the time contain no information about how the measurements were taken, so the cause was overlooked, says David Thompson, first author on the paper and an atmospheric scientist at the State University of Colorado in Boulder. As a result, the bias - which, although small, was large enough to produce the sharp drop in global mean temperature - was never adjusted for.

"The time series is one of the great climate records we have," Thompson says. "During a sabbatical in Britain, I revisited work that I had started a long time ago, and it suddenly occurred to me that the mid-1940s cooling might not necessarily have physical causes."

Thompson discovered the explanation after questioning maritime experts from different countries about the history of shipping, and searching the scientific literature and international databases for scattered bits of relevant information.

"We always thought the observed cooling was real," says Phil Jones, a climate researcher at the University of East Anglia, Norwich, UK, who carried out the study with Thompson. "We did know that there were fewer measurements during the war than before and thereafter, but we simply made wrong assumptions on how and by whom the measurements were taken," he says. "It is pretty clear now that the bias is instrumental.

"It is welcome news for climate modellers. The post-war temperature anomaly has been grossly outside the range of all computer-based climate reconstructions considered by the Intergovernmental Panel on Climate Change (IPCC), and it was prominently featured in the group's 2007 summary for policy-makers.

"The unusual up and down in SSTs in the 1940 s stood out like a sore thumb in the past," says Susan Solomon, a senior scientist at the US National Oceanic and Atmospheric Administration (NOAA) in Boulder, Colorado, and co-chair of the IPCC working group on the physical basis of climate change. "We couldn't explain it, so we showed all the fingers, sore thumb and all," she says.

Climate researchers can now start setting the twentieth-century temperature record straight. The abrupt drop in 1945 will then probably disappear, but what the corrected time series will look like is not yet clear.

And further corrections may come. For example, the gradual shift since the 1970s from (warm-biased) ship-based measurements to (cold-biased) drifting buoys has probably led to a slight underestimate of SST warming, says Richard Reynolds of NOAA's National Climatic Data Center in Asheville, North Carolina. "More data problems will undoubtedly come along, if likely of smaller magnitude," he says.

Climate researchers know from past experience that satellite sensors, radiosondes and ocean profilers are prone to bias. Land measurements are considered much more robust. Climate scientists should think about data quality more often, says Jones, so that there is no opportunity for incorrect data to sow seeds of doubt in people's minds about the reality of climate change.

Quirin Schiermeier 


\section{Beep-beep! Roadrunner breaks petaflop barrier}

The US military's Roadrunner supercomputer has become the first machine to calculate at more than a quadrillion $\left(10^{15}\right)$ operations per second, thereby crossing the petaflop barrier.

The record was technically set on 25 May, in IBM's laboratories in Poughkeepsie, New York, using the LINPACK standard benchmark for comparing supercomputer performance. In early June, however, it achieved petaflop performance on a real-life application of modelling the human cortex, says David Turek, vice-president for 'deep computing' at IBM.

It thus beats the record of IBM's Blue Gene/L machine, based at the Lawrence Livermore National Laboratory in California, which managed about 500 teraflops $\left(10^{12}\right)$.

Roadrunner was built to run calculations to ensure the safety of the US nuclear stockpile, and is due to be delivered next month to the Los Alamos National Laboratory in New Mexico for that purpose. In the meantime, it will also run other calculations, including plasma physics, molecular dynamics and climate change.

\section{Physicist's involvement in historical race row disputed}

A historical investigation has posthumously cleared Eligio Perucca, a physics professor at the Polytechnic University of Turin, of alleged anti-semitism towards Primo Levi.

Levi, an Italian chemist, writer and

Auschwitz survivor, described in his book The Periodic Table the difficulties he had faced in persuading several professors in Turin to take him on as a doctoral candidate in 1940, because of the race laws that the Fascist regime

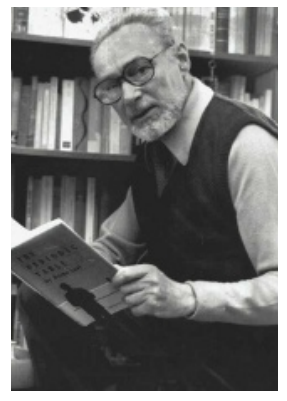

Primo Levi. imposed in Italy at that time. Perucca was later fingered as one of these professors in a Levi biography.

But Bart Kahr, a chemist at the University of Washington in Seattle, has looked into the claim and deduced that Perucca was not a fascist nor an anti-semite.

What's more, the investigation credits Perucca with a chemical discovery - of a certain type of optical activity, called optical rotary dispersion, of dyed chiral sodium chlorate crystals - in 1919 that was thought to have been discovered only in 1931.

\section{Japanese lab installed on space station}

Astronauts installed the main piece of Japan's laboratory module, Kibo, aboard the International Space Station last week.

At 11 metres long, Kibo, delivered by the space shuttle Discovery and opened by Japanese astronaut Akihiko Hoshide (pictured), is the largest pressurized research facility in space. Its final section, for work in unpressurized environments, is slated to be flown up next year. Astronauts also tested Kibo's robotic arm, which will be used to manipulate experiments on that final section when installed.

The station's malfunctioning toilet was also fixed during the trip.

\section{Panel urges further review of controversial NIH lab}

A blue-ribbon panel last week told the National Institutes of Health (NIH) that it needs to conduct more studies if it hopes to see high-risk biosafety research conducted at a lab under construction at Boston University Medical Center in Massachusetts.

The panel, chaired by molecular biologist Adel Mahmoud of Princeton University in New Jersey, said that the agency should conduct risk assessments for 12 dangerous pathogens, including comparing the risks of each being released at urban, suburban and rural sites.

Advisers to NIH director Elias Zerhouni, who received the report on 6 June, offered some sharp criticism of the \$198-million project, most of which is being paid for by the NIH. Community concerns about the risks of the facility have led to it being challenged in both the state and federal courts.

\section{Publications follow policy on stem-cell research}

Countries with less restrictive policies for deriving human embryonic stem cells produce a disproportionate share of the field's publications, according to a new study (A. Levine Cell Stem Cell 2, 521-524; 2008).

By this measure, the United States was the worst performer: although $36 \%$ of scientific publications on human embryonic stem cells in 2006 had a US-based corresponding author, that compared with $46 \%$ of a control set of biomedical publications and $47 \%$ of publications on RNA interference, a less controversial 'hot' technology.

The study's author, bioethicist Aaron Levine of the Georgia Institute of Technology in Atlanta, notes that governments in the top five overperforming countries
(Singapore, United Kingdom, Israel, China and Australia) support research and permit derivation of new cell lines. Besides the United States, other underperformers included Japan, France and Switzerland. Both France and Japan also have less than the expected share of publications on RNA interference, and Levine suggests that scientists in those countries are less inclined to pursue emerging technologies.

\section{Senate climate debate suffers death by hot air}

Democratic leaders in the US Senate walked away empty-handed last week after a highly anticipated debate over climate-change legislation disintegrated into partisan bickering and delaying tactics.

The bill, which would have required a two-thirds cut in greenhouse-gas emissions by 2050 , died on 6 June on a procedural vote. Not a single amendment was considered, and no substantive votes were cast.

Opponents said the legislation would further increase energy prices and push US jobs overseas. The lowlight came as Republicans invoked an obscure Senate rule to force staff to read the entire 492-page bill aloud over the course of some nine hours.

Few had expected the legislation to pass, but Democrats and environmentalists had hoped for a substantive debate that would lay the groundwork for next year.

\section{Corrections}

The News story 'No star left behind' (Nature 453,$437 ; 2008$ ) misstated the number of constellations constructed for an index in starmatching software. The number of constellations is 800 million not 800,000 .

In the News story 'Climate anomaly is an artefact' (Nature 453, 569; 2008) we incorrectly stated that David Thompson was at the State University of Colorado in Boulder. He is in fact at the Colorado State University in Fort Collins. 